\title{
Gambaran nilai budaya dan kearifan lokal dalam film Wood Job!
}

\author{
Raras Arum Wulandari \\ Pasca Sarjana Ilmu Komunikasi Universitas Negeri Sebelas Maret (UNS) Surakarta \\ raztwulandari@gmail.com
}

\begin{abstract}
Wood Job! is a film produced by Japanese theme-rural comedy-drama. The film, directed by Yaguchi Shinobu is an adaptation of the novel "Kamusari naa naa Nichijō"by Miura Shion. It tells a story of a high school student from the city that had to go through life as a forest farmer (lumberjack) in a remote village, with still so many myths, traditions, and the homage. The existences of the film in the community have a unique meaning among other communication media. Besides regarded as effective communication media in the dissemination of ideas and concepts, the film is also a medium of artistic expression provide disclosure paths of creativity, as well as culture media which depict human life and personality of a nation. Film can be considered as the transformation of people's lives, because in the film we can see the reflection of reality. To find out how the overview of cultural values and local wisdom in this film, researcher using a qualitative descriptive analysis with reference to the use of semiotics model of Roland Barthes. Researcher examine the signs appearing through three levels of meaning, denotation, connotation, and myth. Semiotic approach chosen for semiotics can be used to describe many things that are not visible on the surface. Semiotics able to peels more about the hidden meanings in it. This research is expected to broaden the Indonesian peoples to further the preservation of nature, using natural resources wisely. It is unfortunate if Indonesia's forests which are the lungs of the world misused by elements who are not responsible for the sake of mere group.
\end{abstract}

Keywords: Culture, Local Wisdom, Semiotics, Film

\begin{abstract}
Abstrak
Wood Job! adalah sebuah film produksi Jepang yang mengusung tema komedidrama-rural. Film yang disutradarai oleh Shinobu Yaguchi ini merupakan adaptasi dari novel "Kamusari naa naa Nichijō" karya Shion Miura. Mengisahkan tentang seorang pelajar SMA dari kota harus menjalani kehidupan sebagai seorang petani hutan di sebuah desa terpencil, dengan masih begitu banyak mitos, tradisi, dan sisi penghormatan. Keberadaan film di tengah masyarakat mempunyai makna yang unik diantara media komunikasi lainnya. Selain dipandang sebagai media komunikasi yang efektif dalam penyebarluasan ide dan gagasan, film juga merupakan media ekspresi seni yang memberikan jalur pengungkapan kreativitas, serta media budaya yang melukiskan kehidupan manusia dan kepribadian suatu bangsa. Film dapat dikatakan sebagai transformasi kehidupan masyarakat, karena
\end{abstract}




\begin{abstract}
dalam film kita bisa melihat cerminan dari realitas. Untuk mengetahui bagaimana gambaran nilai budaya dan kearifan lokal dalam film ini, peneliti menggunakan analisis deskriptif kualitatif dengan mengacu pada penggunaan model semiotika Roland Barthes. Peneliti mengkaji tanda-tanda yang muncul melalui tiga tingkatan makna, yaitu denotasi, konotasi, dan mitos. Pendekatan semiotika dipilih karena semiotika dapat digunakan untuk menjelaskan berbagai hal yang tidak tampak di permukaan. Semiotika mampu mengupas lebih dalam mengenai makna-makna yang tersembunyi di dalamnya. Penelitian ini diharapkan mampu membuka wawasan masyarakat Indonesia untuk lebih menjaga kelestarian alam, dengan menggunakan sumber daya alam secara bijaksana. Sangat disayangkan jika hutan Indonesia yang merupakan paru-paru dunia disalahgunakan oleh oknum-oknum yang tidak bertanggung jawab demi kepentingan kelompok semata.
\end{abstract}

Kata kunci: Budaya, Kearifan Lokal, Semiotika, Film

\title{
PENDAHULUAN
}

Wood Job! adalah sebuah film bergenre komedi-drama-rural yang berasal dari Jepang. Film yang disutradarai oleh Shinobu Yaguchi ini merupakan adaptasi dari novel “Kamusari naa naa Nichijō” (神去なあなあ日常) karya Shion Miura pada bulan Mei tahun 2009 silam, dan dirilis secara official di Jepang pada tanggal 10 Mei 2014. Mengambil setting lokasi di desa-desa terpencil di perfektur Miu dan perfektur Gifu, yang berada di pegunungan dan dikelilingi oleh hutan belantara. Plot cerita bermula dari seorang pelajar SMA Yuki Hirano (diperankan oleh Shota Sometani) yang gagal dalam ujian masuk universitas, lalu diputuskan oleh pacarnya. Merasa frustasi dengan kesialan yang menimpanya, Yuki akhirnya memutuskan untuk masuk dalam program untuk menjadi seorang jagawana atau petani hutan.

Wood Job! sebenarnya mengusung tema yang sederhana, dan ditampilkan dengan gambar atau adegan yang sederhana pula. Walaupun sederhana, namun tema film ini tergolong antimainstream, jarang dijumpai dalam film lain. Sesuai dengan judulnya, film ini sebagian besar menceritakan tentang bagaimana kehidupan sehari-hari seorang petani hutan. Semangat dan kerja keras mereka, kekuatan fisik dan mental, serta kesadaran diri untuk tidak merusak alam. Pekerjaan menebang dan menanam pohon tidak dilakukan secara sembarangan. Para jagawana melakukannya dengan sangat terampil. Mereka melakukan perhitungan dengan cermat dan teliti, serta tidak melakukan penebangan secara liar, sehingga ekosistem hutan dan kelestarian alam tetap terlindungi.

Film ini memiliki keunikan tersendiri, memperlihatkan sisi lain dari kehidupan di Jepang. Menanggalkan image Jepang yang dikenal dengan kecanggihan teknologinya dan kehidupan masyarakat yang modern, Wood Job! justru yaitu menyuguhkan nuansa alam pedesaan hijau nan asri di pegunungan. Desa terpencil yang jauh dari keramaian dan kebisingan kota, dengan masih begitu banyak mitos, tradisi, dan sisi penghormatan. Menggambarkan sekelompok masyarakat yang memilih untuk hidup sederhana di desa dan tetap mempertahankan tradisi lama mereka.

Dalam film yang sarat akan makna dan pesan moral ini tidak terlepas dari "pesan" tentang nilai-nilai budaya dan kearifan lokal di desa tersebut. Wood Job! juga menyelipkan kritik sosial dan kritik lingkungan hidup ke dalam adegan film. Ada pula 
beberapa sentuhan menarik yang coba ditampilkan dalam film ini tentang 'mistisime', hal-hal yang berhubungan dengan legenda Jepang kuno dan Mitologi Jepang.

Menurut E.B Taylor, kebudayaan adalah keseluruhan kompleks yang meliputi pengetahuan, kepercayaan, kesenian, moral, hukum, adat istiadat, dan kemampuankemampuan lain yang diperoleh manusia sebagai anggota masyarakat. Sedangkan menurut Koentjaraningrat (2005), kebudayaan adalah keseluruhan sistem gagasan, tindakan dan hasil karya manusia dalam rangka kehidupan masyarakat yang dijadikan milik diri manusia dengan belajar. Dari definisi tersebut dapat ditarik kesimpulan bahwa kebudayaan mencakup sesuatu yang kompleks yang diperoleh manusia sebagai anggota masyarakat, dan pembentukannya didukung dan diteruskan pula oleh anggota masyarakat.

Pengertian kearifan lokal dilihat dari kamus Inggris-Indonesia terdiri dari 2 kata, yaitu kearifan (wisdom) dan lokal (local). Local berarti setempat dan wisdom sama dengan kebijaksanaan. Dengan kata lain maka kearifan lokal (local wisdom) dapat dipahami sebagai gagasan-gagasan, nilai-nilai, pandangan-pandangan setempat (lokal) yang bersifat bijaksana, penuh kearifan, bernilai baik, yang tertanam dan diikuti oleh anggota masyarakatnya. Jadi, kearifan lokal merujuk pada lokalitas dan komunitas tertentu.

Kearifan lokal merupakan produk budaya, sesuatu yang berkaitan secara spesifik dengan budaya tertentu serta mencerminkan cara hidup suatu masyarakat tertentu. Kearifan lokal berasal dari dalam masyarakat sendiri, disebarluaskan secara non-formal, dimiliki secara kolektif oleh masyarakat bersangkutan, dikembangkan selama beberapa generasi dan mudah diadaptasi, dan tertanam di dalam cara hidup masyarakat sebagai sarana untuk bertahan hidup. Suatu kearifan lokal dapat menjadi kekuatan ketika pengetahuan dan praktik-praktiknya digunakan secara selaras dengan usaha pembangunan masyarakat.

Berkaitan dengan aspek komunikasi, setiap film yang diproduksi pasti menawarkan suatu pesan kepada orang yang menontonnya, baik ditampilkan secara tersirat maupun tersurat. Sang pembuat film atau sutradara berusaha untuk merepresentasikan ide atau gagasan yang dimilikinya. Ide atau gagasan tersebut lalu dibungkus dalam sebuah cerita agar dapat dikomunikasikan dengan baik kepada para penontonnya. Film dianggap sebagai sarana yang ampuh untuk memasukkan, memasarkan, dan menyebarluaskan ide, gagasan, nilai-nilai, serta ideologi tertentu.

Film hadir sebagai kebudayaan massa yang muncul seiring dengan perkembangan masyarakat yang semakin modern, sebagai bagian dari budaya massa yang populer. Budaya populer didefinisikan oleh kepercayaan dan nilai, oleh perilaku dan nilai, dan oleh pemahaman terhadap sejarah dan terhadap keberadaan. Semua hal tersebut dimiliki oleh kelompok sosial tertentu (Burton, 2012:52). Keberadaan film di tengah masyarakat mempunyai makna yang unik diantara media komunikasi lainnya. Selain dipandang sebagai media komunikasi yang efektif dalam penyebarluasan ide dan gagasan, film juga merupakan media ekspresi seni yang memberikan jalur pengungkapan kreativitas, dan media budaya yang melukiskan kehidupan manusia dan kepribadian suatu bangsa.

Film dapat dikatakan sebagai transformasi kehidupan masyarakat, karena dalam film kita bisa melihat gambaran atau cerminan yang sebenarnya. Bahkan terkadang kita tidak menyadarinya. Film juga memiliki dua fungsi, sebagai refleksi atau sebagai representasi masyarakat. Sebagai refleksi kenyataan, sebuah film hanya memindahkan 
kenyataan ke layar tanpa mengubah kenyataan tersebut, misalnya film dokumentasi atau dokumenter, upacara kenegaraan atau film dokumentasi peristiwa perang. Sedangkan sebagai representasi kenyataan berarti film tersebut membentuk dan menghadirkan kembali kenyataan berdasarkan kode-kode, konvensi dan ideologi dari kebudayaan. (Sobur, 2009). Film merupakan cermin dari realitas, reproduksi dari kenyataan seperti apa adanya. Realitas yang ingin ditampilkan memiliki ciri yang berbeda-beda, tergantung dari sudut pandang sutradara atau si pembuat film. Beberapa aspek yang ditampilkan misalnya realitas sosial, politik, ekonomi, hukum, dan budaya.

\section{Kerangka Teori}

Dalam banyak penelitian tentang dampak film terhadap khalayak, hubungan antara film dan khalayak selalu dipahami secara linier. Artinya, film selalu mempengaruhi dan membentuk khalayak berdasarkan muatan pesan didalamnya, tanpa pernah berlaku sebaliknya. Unsur film berkaitan erat dengan karakteristik utama, yaitu audio visual. Maka dari itu, yang terpenting dalam film adalah suara, gambar, musik film, dan kata-kata yang diucapkan (dialog) dalam adegan (Sobur, 2009).

Film umumnya dibangun dengan banyak tanda. Tanda-tanda itu termasuk berbagai sistem tanda yang bekerja sama dengan baik dalam upaya mencapai efek yang diharapkan. Pada dasarnya tanda-tanda dalam film terdiri dari tanda verbal dan nonverbal. Tanda verbal mencakup bahasa yang kita kenal, sedangkan tanda nonverbal adalah bentuk tampilan dan warna yang disajikan dalam film. Tanda-tanda dalam film mengacu pada suatu rencana konstruksi berisi positioning pada karakteristik audiens tujuan. Untuk itu diperlukan suatu tampilan yang sesuai dengan karakteristik pasar ataupun penonton.

Tanda dan komunikasi tidak bisa dipisahkan, mereka saling berhubungan erat satu sama lain. Seperti yang diungkapkan oleh L.E Sarbaugh : "Komunikasi merupakan proses penggunaan tanda-tanda dan simbol-simbol yang mendatangkan makna bagi orang atau orang-orang lain" (Sarbaugh, 1993:2). Sama halnya dengan Theodorson dan Theodorson yang memberikan suatu definisi yang menekankan pada penggunaan tanda atau simbol-simbol dalam komunikasi. Menurut mereka komunikasi adalah transisi dari informasi ide, perilaku atau emosi dari satu individu atau kelompok kepada lainnya terutama melalui simbol. Definisi ini mengatakan bahwa komunikasi menekankan pada pengiriman pesan dengan media utama simbol sebagai wahana pengiriman pesan.

Agar pesan dapat diterima secara efektif, maka diperlukan adanya proses interpretasi terhadap pesan tersebut. Maka berkembanglah cabang ilmu yang membahas tentang bagaimana memahami simbol atau lambang, yaitu semiotika (semiotics) atau semiologi (semiology), yaitu ilmu tentang interpretasi tanda.

Selain Ferdinand D. Saussure dan Charles S. Peirce, salah satu tokoh dalam semiotika lainnya adalah Roland Barthes, yang dikenal sebagai salah seorang pemikir strukturalis. Teori semiotik Barthes hampir secara harfiah diturunkan dari teori linguistik Saussure. Barthes mengungkapkan bahwa bahasa merupakan sebuah sistem tanda yang mencerminkan asumsi-asumsi dari masyarakat tertentu dalam waktu tertentu (Sobur, 2003 dalam Nawiroh Vera, 2014).

Barthes melontarkan konsep tentang konotasi dan denotasi sebagai kunci dari analisisnya. Bila Saussure hanya menekankan pada penandaan dalam tataran denotatif, maka Barthes menyempurnakan semiotika Saussure dengan mengembangkan sistem 
penandaan pada tingkat konotatif. Barthes mengembangkan semiotika Saussure dengan sistem penandaan bertingkat yang disebut denotasi dan konotasi. Ia juga melihat aspek lain dari penandaan, yaitu "mitos" yang menandai masyarakat.

\begin{tabular}{|c|c|}
\hline $\begin{array}{c}1 . \\
\text { Signifier } \\
\text { (penanda) }\end{array}$ & $\begin{array}{c}2 . \\
\text { Signified } \\
\text { (petanda) }\end{array}$ \\
\hline $\begin{array}{c}3 . \\
\text { Denotative Sign } \\
\text { (tanda denotatif) }\end{array}$ & \\
\hline $\begin{array}{c}4 . \\
\text { Connotative Signifier } \\
\text { (penanda konotatif) }\end{array}$ & $\begin{array}{c}\text { Connotative Signified } \\
\text { (petanda konotatif) }\end{array}$ \\
\hline 6. & \\
Connotative Sign \\
(tanda konotatif)
\end{tabular}

Tabel 1. Peta Tanda Roland Barthes

Dari peta tanda diatas, terlihat bahwa tanda denotatif (3) terdiri atas penanda (1) dan petanda (2). Akan tetapi, pada saat bersamaan, tanda denotatif adalah juga penanda konotatif (4). Denotasi merupakan tataran pertama yang maknanya bersifat tertutup. Tataran denotasi menghasilkan makna yang eksplisit, langsung, dan pasti. Denotasi merupakan makna yang sebenarnya, yang disepakati bersama secara sosial, yang rujukannya pada realitas. Konotasi merupakan tanda yang penandanya mempunyai keterbukaan makna dan menghasilkan makna yang implisit, tidak langsung, dan tidak pasti.

Dalam semiotika Barthes, denotasi merupakan sistem signifikansi tingkat pertama, sedangkan konotasi merupakan sistem signifikansi tingkat kedua. Dengan kata lain denotasi adalah makna objektif yang tetap, sedangkan konotasi adalah makna subjektif yang bervariasi. Konotasi identik dengan operasi ideologi, yang disebutnya sebagai 'mitos' dan berfungsi untuk mengungkapkan dan memberikan pembenaran bagi nilainilai dominan yang berlaku dalam suatu periode tertentu.

Pada mitos juga terdapat pola tiga dimensi penanda, pertanda, dan tanda. Sebagai suatu sistem yang unik, mitos dibangun oleh suatu rantai pemaknaan yang telah ada sebelumnya. Dengan kata lain, mitos adalah juga suatu sistem pemaknaan tataran kedua. Pada mitos pula, sebuah petanda dapat memiliki beberapa penanda (Budiman, 2001:28 dalam Sobur, 2004:71).

Dalam melakukan aktivitas sosialnya, setiap individu pasti berpedoman kepada nilai-nilai atau sistem nilai yang ada dan hidup dalam masyarakat itu sendiri. Suatu nilai yang sudah tertanam dalam diri seseorang akan dijadikan petunjuk atau acuan dalam bertingkah laku. Nilai-nilai tersebut banyak mempengaruhi sikap dan perilaku seseorang tentang pandangan benar dan salah, baik dan buruk, atau pantas dan tidak pantas. 
Clyde Kluckhohn dalam Pelly (1994), mengemukakan bahwa nilai budaya adalah suatu konsep dengan ruang lingkup luas yang hidup dalam alam fikiran sebagian besar masyarakat mengenai apa yang paling berharga dalam hidup. Rangkaian konsep tersebut merupakan sebuah sistem nilai budaya yang saling berkaitan satu sama lain. Menurut Kluckhohn, terdapat lima masalah dasar dalam kehidupan manusia di setiap kebudayaan yang dapat ditemukan secara universal. Kelima masalah tersebut adalah :

1. Hakikat Hidup (MH)

2. Hakikat Karya (MK)

3. Hakikat Kedudukan Manusia dalam Ruang dan Waktu (MW)

4. Hakikat Hubungan Manusia dengan Alam (MA)

5. Hakikat Hubungan Manusia dengan Sesamanya (MM)

\section{Operasionalisasi Konsep \\ Semiotika}

Semiotika adalah suatu ilmu atau metode analisis untuk mengkaji tanda. Tandatanda adalah perangkat yang dipakai dalam upaya berusaha mencari jalan di kehidupan ini, di tengah-tengah manusia dan bersama dengan manusia. Tradisi semiotika mencakup teori utama mengenai bagaimana tanda mewakili objek, ide, situasi, keadaan, perasaan, dan sebagainya yang berada diluar diri (Morissan, 2013:27).

Pengertian semiotika sebagai suatu model dari ilmu pengetahuan sosial memahami dunia sebagai sistem hubungan yang memiliki unit dasar yang disebut "tanda" dengan demikian semiotika mempelajari hakekat tentang keberadaan tanda, baik itu dikonstruksikan oleh simbol dan kata-kata yang digunakan dalam konteks sosial (Sobur, 2003:87). Semiotika dipakai sebagai pendekatan untuk menganalisa suatu baik itu berupa teks gambar ataupun symbol di dalam media cetak ataupun elektronik. Dengan asumsi media itu sendiri dikomunikasikan dengan simbol dan kata.

\section{Film}

Menurut Kamus Besar Bahasa Indonesia, film dapat diartikan dalam dua pengertian. Yang pertama, film merupakan sebuah selaput tipis berbahan seluloid yang digunakan untuk menyimpan gambar negatif dari sebuah objek. Yang kedua, film diartikan sebagai lakon atau gambar hidup. Pengertian lebih lengkap dan mendalam tercantum jelas dalam pasal 1 ayat (1) UU Nomor 8 tahun 1992 tentang Perfilman Nasional, dijelaskan bahwa film adalah karya cipta seni dan budaya yang merupakan media komunikasi massa pandang-dengar yang dibuat berdasarkan asas sinematografi dengan direkam pada pita seluloid, pita video, piringan video dan/atau bahan hasil penemuan teknologi lainnya dalam segala bentuk, jenis, dan ukuran yang ditayangkan dengan sistem proyeksi mekanik, elektronik dan/atau lainnya (Mabruri, 2013).

Sedangkan menurut Effendi (1986), film diartikan sebagai hasil budaya dan alat ekspresi kesenian. Film sebagai komunikasi massa merupakan gabungan dari berbagai teknologi seperti fotografi dan rekaman suara, kesenian baik seni rupa dan seni teater sastra dan arsitektur serta seni musik.

\section{Nilai Budaya dan Kearifan Lokal}

Clyde Kluckhohn (dalam Pelly, 1994) mendefinisikan nilai budaya sebagai konsepsi umum yang terorganisasi, yang mempengaruhi perilaku yang berhubungan 
dengan alam, kedudukan manusia dalam alam, hubungan sesama manusia tentang halhal yang diinginkan atau tidak diinginkan yang mungkin bertalian dengan hubungan manusia dengan lingkungan dan sesama manusia. Sedangkan menurut Koentjaraningrat, nilai budaya terdiri dari konsepsi-konsepsi yang hidup dalam alam fikiran sebagian besar masyarakat mengenai hal-hal yang mereka anggap sangat mulia. Sistem nilai yang ada dalam suatu masyarakat dijadikan orientasi dan rujukan dalam bertindak. Oleh karena itu, nilai budaya yang dimiliki seseorang mempengaruhinya dalam menentukan alternatif, cara-cara, alat-alat, dan tujuan-tujuan pembuatan yang tersedia. (http://wirasaputra.wordpress.com/2011/10/13/nilai-budaya-sistem-nilai-dan-orientasinilai-budaya).

Nilai-nilai budaya yang dipertahankan oleh masyarakat kemudian akan berubah menjadi sebuah tradisi, sekaligus merupakan identitas budaya bagi masyarakat tersebut. Jika produk budaya berusaha untuk dipertahankan secara turun temurun dari waktu ke waktu, maka dengan sendirinya nilai budaya itu akan menjadi proyek dalam membentuk identitas budaya lokal.

Selanjutnya, nilai yang terdapat dalam budaya lokal itu disebut kearifan lokal. Kearifan lokal merupakan produk budaya, sesuatu yang berkaitan secara spesifik dengan budaya tertentu serta mencerminkan cara hidup suatu masyarakat tertentu. Kearifan lokal merupakan cara-cara dan praktik-praktik yang dikembangkan oleh sekelompok masyarakat yang berasal dari pemahaman mendalam mereka akan lingkungan setempat yang terbentuk dari tinggal di tempat tersebut secara turun temurun. (http://duniaglobalislam.blogspot.co.id/2011/05/ dakwah-dengan-berpijakpada-kearifan.html).

Dari penjelasan itu dapat dilihat bahwa kearifan lokal merupakan langkah penerapan dari tradisi yang diterjemahkan dalam artefak fisik. Hal terpenting dari kearifan lokal adalah proses sebelum implementasi tradisi pada artefak fisik, yaitu nilainilai dari alam untuk mengajak dan mengajarkan tentang bagaimana membaca potensi alam dan menuliskannya kembali sebagai tradisi yang diterima secara universal oleh masyarakat, khususnya dalam berarsitektur. Nilai tradisi untuk menyelaraskan kehidupan manusia dengan alam lingkungan.

\section{Metodologi Penelitian}

Pada penelitian kali ini, peneliti menggunakan pendekatan kualitatif yang berlandaskan paradigma kritis. Paradigma kritis pada dasarnya adalah paradigma ilmu pengetahuan yang meletakkan epistemologi kritik Marxisme dalam seluruh metodologi penelitiannya. Asumsi dasar dalam paradigma kritis berkaitan dengan keyakinan bahwa ada kekuatan laten dalam masyarakat yang begitu berkuasa mengontrol proses komunikasi masyarakat. Hal ini berarti paradigma kritis melihat adanya "realitas" dibalik kontrol komunikasi masyarakat.

Dalam penelitian ini, fenomena yang diteliti adalah gambaran nilai budaya dan kearifan lokal dalam film Wood Job! dengan menggunakan metode semiotika, yakni sebuah metode untuk mengkaji tanda-tanda. Pemilihan pendekatan semiotika dalam penelitian ini dipilih karena semiotika dapat digunakan untuk menjelaskan berbagai hal yang tidak tampak di permukaan. Semiotika mampu mengupas lebih dalam mengenai makna-makna yang tersembunyi didalamnya, sehingga akan sangat menentukan kedalaman dan keluasan informasi yang diperoleh. 
Metode semiotika yang digunakan peneliti adalah model semiotika dari Roland Barthes. Peneliti mengkaji tanda dengan menggunakan tiga tingkatan makna, yakni denotasi, konotasi, dan mitos, serta ideologi dibalik itu.

Adapun yang menjadi subjek penelitian ini adalah Film Wood Job! dan objek penelitiannya adalah nilai budaya dan kearifan lokal dalam film tersebut. Agar lebih fokus, peneliti mengklasifikasikan nilai budaya dan kearifan lokal menjadi 5 objek, dengan menggunakan konsep nilai budaya dari Clyde Kluckhohn.

\section{HASIL DAN PEMBAHASAN}

Film merupakan cermin dari realitas, reproduksi dari kenyataan seperti apa adanya. Realitas yang ingin ditampilkan memiliki ciri yang berbeda-beda, tergantung dari sudut pandang sutradara atau si pembuat film. Beberapa aspek yang ditampilkan misalnya realitas sosial, politik, ekonomi, hukum, dan budaya. Seperti halnya Shinobu Yaguchi, yang mencoba menggambarkan sebuah realitas yang ada di masyarakat pedesaan Jepang tentang nilai-nilai budaya dan kearifan lokal yang telah diwariskan secara turun-temurun. Shinobu kemudian membentuk dan menghadirkan kembali kenyataan tersebut dalam sebuah film dengan judul "Wood Job!" berdasarkan kodekode, konvensi, dan ideologi dari kebudayaan.

Berbicara mengenai nilai budaya dan kearifan lokal, penulis menggunakan konsep nilai budaya Clyde Kluckhohn mengenai konsep nilai, sistem nilai, dan orientasi nilai budaya, serta lima masalah dasar dalam hidup. Penulis mengklasifikasikan nilai budaya dan kearifan lokal dalam film ini dengan menggunakan konsep budaya Kluckhohn untuk kemudian dikaji dengan menggunakan analisis semiotika.

\begin{tabular}{|c|c|c|c|}
\hline $\begin{array}{c}\text { Masalah Dasar } \\
\text { dalam Hidup }\end{array}$ & \multicolumn{3}{|c|}{ Orientasi Nilai Budaya } \\
\hline $\begin{array}{c}\text { Hakikat hidup } \\
\text { (MH) }\end{array}$ & Hidup itu buruk & Hidup itu baik & $\begin{array}{c}\text { Hidup itu buruk, } \\
\text { tetapi manusia dapat } \\
\text { berusaha agar hidup } \\
\text { itu menjadi baik }\end{array}$ \\
\hline $\begin{array}{c}\text { Hakikat karya } \\
\text { (MK) }\end{array}$ & $\begin{array}{c}\text { Karya itu untuk } \\
\text { nafkah hidup }\end{array}$ & $\begin{array}{c}\text { Karya itu untuk } \\
\text { kedudukan, } \\
\text { kehormatan, dsb. }\end{array}$ & $\begin{array}{c}\text { Karya itu untuk } \\
\text { menambah karya }\end{array}$ \\
\hline $\begin{array}{c}\text { Hakikat } \\
\text { kedudukan } \\
\text { manusia dalam } \\
\text { ruang dan } \\
\text { waktu (MW) }\end{array}$ & $\begin{array}{c}\text { Orientasi ke } \\
\text { masa lalu }\end{array}$ & $\begin{array}{c}\text { Orientasi ke } \\
\text { masa kini }\end{array}$ & $\begin{array}{c}\text { Orientasi ke masa } \\
\text { depan }\end{array}$ \\
\hline $\begin{array}{c}\text { Hakikat } \\
\text { hubungan } \\
\text { manusia dengan } \\
\text { alam (MA) }\end{array}$ & $\begin{array}{c}\text { Manusia tunduk } \\
\text { kepada alam } \\
\text { yang dahsyat }\end{array}$ & $\begin{array}{c}\text { Manusia menjaga } \\
\text { keselarasan } \\
\text { dengan alam }\end{array}$ & $\begin{array}{c}\text { Manusia berusaha } \\
\text { menaklukkan dan } \\
\text { menguasai alam }\end{array}$ \\
\hline
\end{tabular}




\begin{tabular}{|c|c|c|c|}
\hline $\begin{array}{c}\text { Hakikat } \\
\text { hubungan } \\
\text { manusia dengan } \\
\text { sesamanya } \\
(\mathrm{MM})\end{array}$ & $\begin{array}{c}\text { Orientasi } \\
\text { horizontal, rasa } \\
\text { ketergantungan } \\
\text { kepada } \\
\text { sesamanya }\end{array}$ & $\begin{array}{c}\text { Orientasi } \\
\text { vertikal, rasa } \\
\text { ketergantungan } \\
\text { kepada atasan } \\
\text { dan berpangkat }\end{array}$ & $\begin{array}{l}\text { Individualisme, } \\
\text { menilai tinggi usaha } \\
\text { atas kekuatan } \\
\text { sendiri }\end{array}$ \\
\hline
\end{tabular}

Tabel 2. Kerangka Kluckhohn

Dalam masalah hakikat hidup manusia $(\mathrm{MH})$, ada kebudayaan yang memandang bahwa hidup itu buruk, maka perlu dihindari. Ada kebudayaan lain yang memandang bahwa hidup itu baik adanya, dan ada pula yang menganggap bahwa hidup itu sebenarnya buruk, tetapi manusia dapat mengusahakannya supaya menjadi baik. Ada dua orientasi nilai budaya mengenai hakikat hidup di film ini. Pertama ditampilkan melalui tokoh Yuki, yang sebagai orang kota ia menganggap hidup di desa itu buruk. Kedua ditampilkan melalui karakter masyarakat desa Kamusari, yang menganggap hidup di desa itu baik karena merupakan anugerah dari Tuhan.

Pada menit-menit awal film diperlihatkan saat Yuki baru menginjakkan kaki di desa, ada adegan Yuki yang kesal karena tidak bisa mendapatkan sinyal ponsel. Ada juga adegan saat Yuki menggunakan semprotan anti serangga karena merasa terganggu dengan serangga hutan. Dari adegan tersebut terlihat bahwa Yuki tidak menyukai hidup di desa.
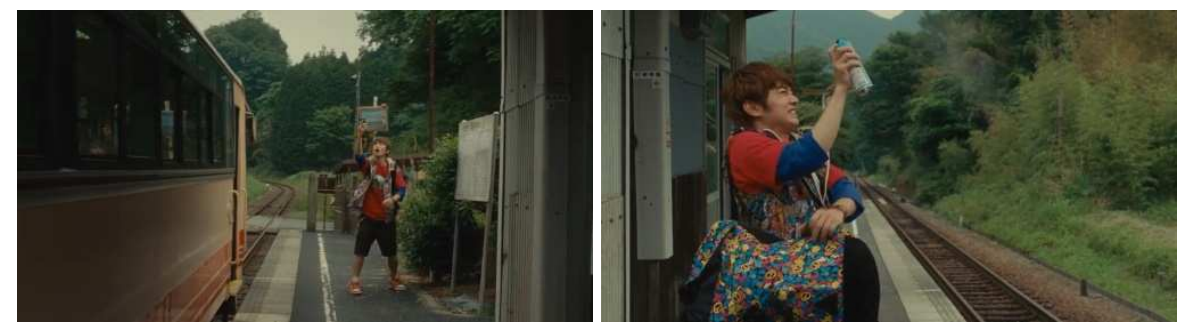

Gambar 1. Yuki mencari sinyal ponsel dan menyemprotkan anti-serangga

Selanjutnya ada adegan saat beberapa mahasiswa yang sedang melakukan observasi di desa Kamusari bercakap-cakap dengan Yuki. Dalam dialog yang terjadi, terlihat bahwa mereka (para mahasiswa) menganggap hidup di desa ini buruk. Dialog pertama dilakukan oleh salah satu mahasiswa pria yang mengatakan : "Saat Reina bilang seorang teman SMAnya tiba-tiba bekerja di hutan dan pergi dari kota, aku berpikir apa dia akan baik-baik saja?". Dia melanjutkan : "Berapa lama lagi kau akan tinggal disini? Seperti di penjara saja" dan mahasiswa lain ikut tertawa.

Dari dialog tersebut, secara tersirat menjelaskan bahwa mahasiswa tersebut berpikir Yuki pasti akan hidup sengsara disini. Dia ragu apakah Yuki akan baik-baik saja hidup bagaikan seorang tawanan di penjara. Ini menggambarkan seolah-olah masyarakat perkotaan memandang hidup di desa sungguh buruk. Hal tersebut diperkuat oleh dialog selanjutnya yang dilakukan oleh mahasiswi wanita yang mengatakan : "Kalau aku tidak akan pernah bisa hidup disini!"

Orientasi nilai budaya yang kedua ditampilkan pada menit ke 00:30:05 melalui karakter masyarakat desa Kamusari. Masyarakat menganggap bahwa kehidupan yang 
mereka peroleh adalah baik adanya, dan merupakan anugerah dari Tuhan yang wajib disyukuri. Salah satunya adalah adegan saat para pekerja Nakamura Lumber sedang duduk diatas mobil pickup dan bernyanyi bersama-sama. Pada adegan tersebut terlihat jelas ekspresi wajah mereka yang tersenyum bahagia walaupun dalam kondisi lelah setelah bekerja.

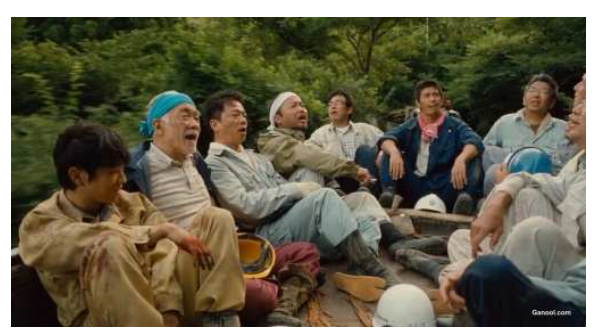

Gambar 2. Para pekerja bernyanyi di atas mobil pickup

Hal tersebut menunjukkan bahwa mereka bekerja dengan senang hati, mensyukuri apa yang telah digariskan oleh Tuhan. Selain itu, bentuk ketulusan para pekerja juga terlihat dari lirik lagu yang mereka nyanyikan sebagai berikut: "Kami menebang pohon dan kami minum, makan, lalu turun Makan dengan hati kita... Dan mendengkur seperti sapi " Mereka sangat menyadari hakikat hidup yang sebenarnya. Hidup ini mungkin buruk dengan segala keterbatasannya, namun manusia harus berusaha untuk membuat hidup menjadi lebih baik. Salah satunya adalah dengan cara bersyukur, mencintai dan menikmati pekerjaannya.

Mengenai masalah Hakikat Karya (MK), ada kebudayaan yang memandang bahwa karya manusia diciptakan untuk menafkahi hidup. Ada kebudayaan yang menganggap sebuah karya diciptakan untuk memberikan manusia kedudukan atau kehormatan di masyarakat, dan ada pula kebudayaan lain yang beranggapan bahwa karya manusia diciptakan untuk menghasilkan lebih banyak karya lain.

Pada menit ke 00:51:34 ada adegan saat Seiichi menunjukkan sistem GPS di komputernya kepada Yuki. Dengan menggunakan sistem GPS, Seiichi dengan mudah memetakan hutan dengan cepat dan akurat. Dalam adegan tersebut Seiichi memberikan penjelasan : "Kami melakukan survei dengan GPS. Sistem Informasi Geografis memberikan kita peta pengelolaan hutan. Dulu kami harus berjalan dan menggambar setiap tanda di peta"

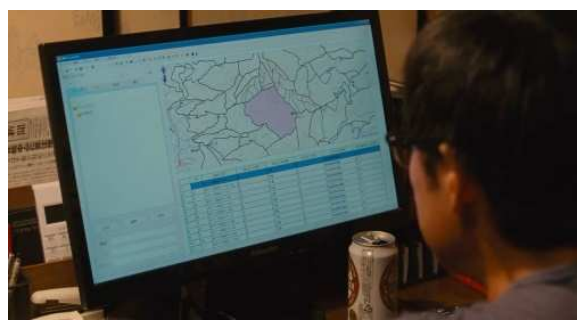

Gambar 3. Sistem GPS di komputer Seiichi

Seiichi menganggap dengan adanya sistem GPS ini akan lebih memudahkan pekerjaan mereka. Pemetaan yang cepat dan akurat dapat mempermudah pengelolaan hutan, dan hal itu berkesinambungan dengan menghasilkan log kayu yang lebih banyak 
dengan kualitas terbaik. Selain itu ada pula adegan saat Seiichi dan Yoki mengajak Yuki untuk menjual hasil tebangan mereka. Seiichi mengatakan bahwa hasil penebangan mereka lebih baik kualitasnya dibandingkan dengan yang lain, karena telah memperhitungkan dengan baik kapan waktu yang tepat untuk menebang pohon berusia 105 tahun. Log kayu hasil tebangan mereka juga terjual dengan harga fantastis, yakni 800.000 Yen. Jika diterapkan dalam konteks hakikat karya (HK), log kayu hasil tebangan mereka merupakan sebuah karya, kemudian mereka menjualnya untuk nafkah hidup mereka.

Untuk masalah persepsi manusia terhadap waktu (MW), ada kebudayaan yang selalu berorientasi ke masa lalu, menganggap masa lalu adalah yang paling penting. Ada juga kebudayaan yang berorientasi ke masa kini, menganggap hidup yang terpenting adalah masa kini. Serta ada kebudayaan lain yang berorientasi ke masa depan, memandang masa depan sebagai kehidupan yang paling penting.

Dalam film ini, Shinobu lebih menonjolkan kebudayaan yang berorientasi ke depan. Misalnya pada menit ke 00:42:03, terdapat adegan dan dialog saat para petani hutan sedang menanam ratusan bibit pohon. Mereka harus menanamnya satu persatu di lahan seluas hampir 1 hektar dengan menggunakan tangan, tanpa alat bantu apapun. Adegan ini memperlihatkan bentuk persepsi manusia terhadap waktu dengan berorientasi pada masa yang akan datang. Para petani hutan menanam ratusan bibit pohon untuk jangka panjang.
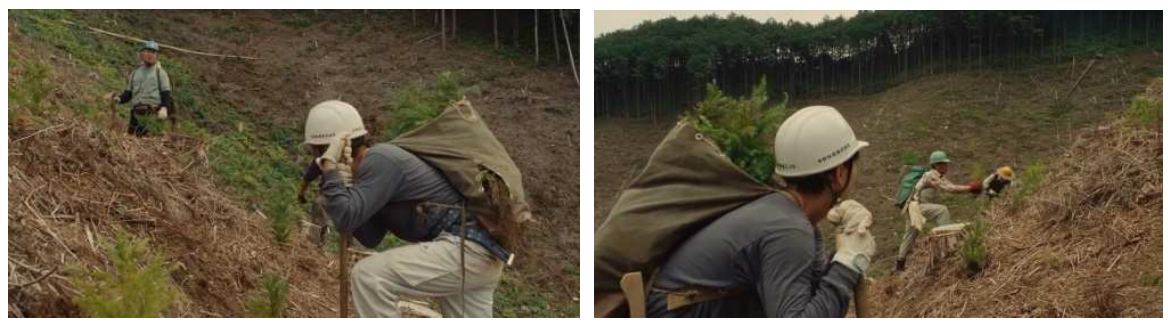

Gambar 4. Yuki dan para petani hutan menanam bibit pohon

Orientasi pada masa depan juga terdapat pada menit ke 00:58:33 melalui dialog yang terjadi antar ketiga tokoh tadi. Dialog yang terjadi adalah sebagai berikut :

Yuki : "800.000 Yen untuk satu log! Jika dihitung semuanya... Bersihkan saja seluruh hutan dan kau akan jadi jutawan!"

Seiichi : "Mungkin"

Yuki : "Mengapa kau mengendarai mobil ini? Kau bisa punya Mercedes!"

Yoki : "Apa kau bodoh?! Itu bukan hanya seumur hidupmu, kau tahu. Apa yang tersisa untuk generasi berikutnya jika kita menjual seluruh pohon nenek moyang kita? Apa yang akan anak-anak kita lakukan?"

Seiichi : "Kami terus menanam bibit dan merawat mereka sampai besar. Ini pekerjaan yang aneh. Petani memanen hasil panen mereka setiap musimnya, tapi kami tidak. Kelak saat hasil kerja kami dihargai, kami semua mungkin sudah mati. Begitulah seterusnya"

Dari penggalan dialog diatas sangat jelas bahwa Seiichi dan Yoki sebagai masyarakat desa tersebut beranggapan bahwa memikirkan masa depan adalah hal yang terpenting. Kita harus menghargai usaha dan kerja keras nenek moyang kita. Selain itu kita juga tidak boleh serakah karena masih akan ada kehidupan berikutnya untuk anak- 
cucu kita kelak. Jangan berorientasi pada masa kini saja, tapi berorientasilah untuk masa yang akan datang.

Tidak hanya orientasi ke masa depan, beberapa adegan dalam film ini juga memperlihatkan masyarakat yang masih berorientasi pada masa lalu. Masyarakat yang masih berorientasi pada masa lalu umumnya adalah orang-orang tua yang selalu berpikir dengan cara yang dulu. Mereka akan merasa kesulitan saat dihadapkan pada persoalan masa kini atau masa depan. Salah satunya terdapat pada dialog antara Yoki dan Yuki yang sedang bersantai menikmati hari libur mereka. Saat itu adalah hari libur para petani hutan, dan siapapun dilarang masuk dan beraktivitas di dalam hutan. Yuki yang tidak tahu meminta penjelasan dari Yoki :

"Hari ini adalah hari yang tidak bagus untuk pergi ke hutan" // "Kenapa?" "Hari ini Dewi sedang menghitung pohon-pohon miliknya" // "Lagi-lagi tentang Dewi itu?" // "Pernah ada seseorang yang mencoba ke hutan dan menghitung pohon-pohon itu, entah bagaimana orang itu menghilang"

Dari penggalan dialog diatas menunjukkan bahwa Yoki dan masyarakat setempat, masih percaya pada mitos tersebut. Hal itu diperkuat oleh dialog di menit ke 01:21:47, saat adegan beberapa warga yang terpaksa masuk ke dalam hutan untuk mencari Kenji, cucu dari Kepala Desa Toshiro yang menghilang di hutan. "Jika sudah jauh masuk ke dalam hutan, mereka takkan bisa menemukannya". Mereka mengkhawatirkan keselamatan warga yang masuk ke dalam hutan, karena apa yang mereka yakini selama ini adalah tidak akan ada seorang pun yang selamat jika memasuki hutan pada hari terlarang.

Dalam persepsi manusia terhadap alam (MA), ada kebudayaan yang menganggap bahwa manusia hanya dapat tunduk pada kekuasaan alam yang dahsyat. Ada kebudayaan yang menganggap bahwa manusia harus berusaha mencari keselarasan hidup dengan alam. Selain itu ada juga kebudayaan yang beranggapan bahwa alam merupakan sesuatu yang harus ditaklukkan dan dikuasai oleh manusia.

Bentuk menjaga keselarasan dengan alam yang paling menonjol dalam film ini adalah saat masyarakat desa Kamusari menagdakan festival akbar 'Dewi Gunung'. Adegan ini mulai terlihat di menit ke 01:29:35, saat seluruh warga desa Kamusari sedang membuat persiapan untuk festival akbar. Mereka yang tidak ikut mengambil bagian utama dalam festival bekerja sama mempersiapkan segala keperluan festival. Setelah itu secara berurutan Shinobu menampilkan adegan prosesi festival akbar dari tahap awal persiapan, hingga festival berakhir.

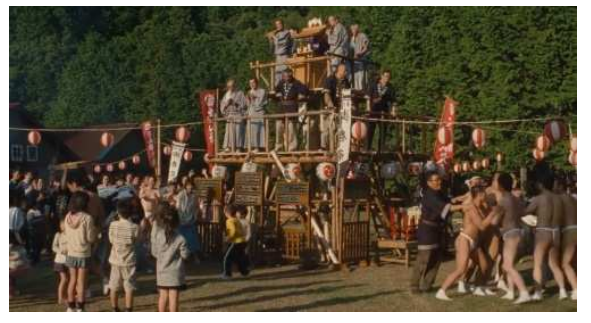

Gambar 5. Persiapan festival akbar 'Dewi Gunung' 
Sebelum melakukan ritual, masyarakat yang merupakan bagian utama (pria dewasa) mengenakan fundoshi, pakaian dalam tradisional di Jepang. Di menit ke 01:30:44 ada adegan penduduk pria yang menyiramkan beberapa gayung air ke tubuhnya. Hal itu dimaknai sebagai 'penyucian diri', karena mereka akan mengadakan upacara sakral untuk sang dewi gunung. Mereka harus bersih dan suci untuk bertemu dengan Dewi yang telah memberikan kemakmuran dan kesejahteraan bagi mereka selama ini.

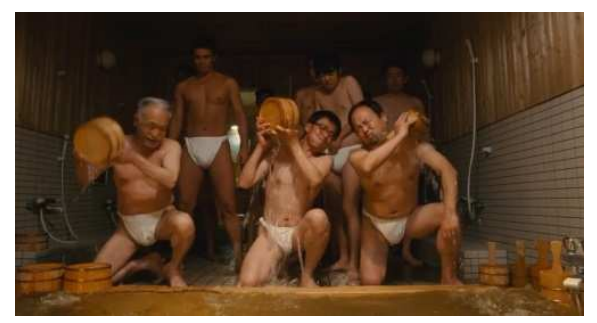

Gambar 6. Persiapan festival akbar 'Dewi Gunung'
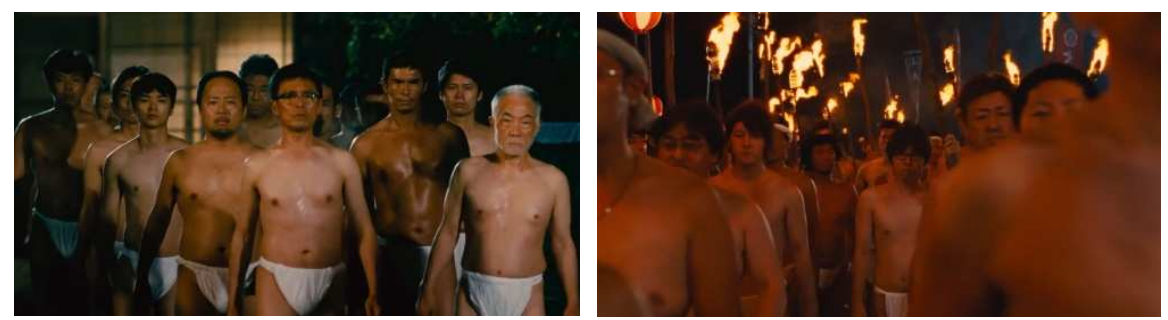

Gambar 7. Para penduduk berbaris dan mulai berjalan menuju puncak gunung

Pada menit ke 01:36:05 ada adegan saat Seiichi membaca syair pemujaan untuk Dewi Gunung. Dalam ritual tersebut, Seiichi berperan sebagai pemimpin rombongan. Syair tersebut berbunyi : "Kami meminta izin untuk berbicara, oh Dewi Gunung yang agung, oh sang Dewi, dan kepada leluhur sebelum Dewi kami. Kami kemari untuk memberikan penghormatan kepadamu dalam Festival Akbar yang ke-48 tahun ini. Kami warga Kamusari berkumpul untuk menyembahmu. Kami tidak berbicara pada diri kami sendiri, semoga kekuatanmu kembali mengalir dalam ketenangan yang setulus-tulusnya"

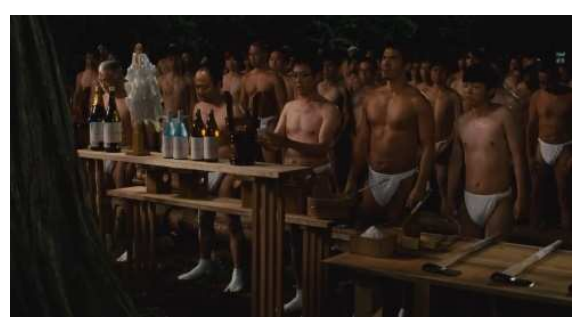

Gambar 8. Seiichi membacakan syair pemujaan 
Isi syair yang dibacakan oleh Seiichi merupakan bentuk rasa syukur dan penghormatan masyarakat terhadap Dewi Gunung. Pembacaan syair ini dilakukan saat mendekati fajar. Setelah fajar mulai terbit, mereka mulai bekerja sama menebang pohon tersebut. Ritual ini bertujuan untuk memberikan persembahan terbaik bagi sang dewi, dengan menumbangkan pohon raksasa yang telah berusia ratusan tahun.

Aspek nilai budaya yang terakhir adalah mengenai masalah hakikat hubungan manusia dengan sesamanya (MM). Ada kebudayaan yang mementingkan hubungan horizontal, artinya lebih mengutamakan hubungan yang saling bekerja sama atau gotong-royong. Ada juga kebudayaan yang mementingkan hubungan vertikal, artinya lebih mengutamakan hubungan antar sesama manusia yang termasuk atasan, tokoh masyarakat, dan orang-orang berpangkat. Ada pula kebudayaan lain yang mementingkan individualisme, menganggap bahwa hidup manusia tidak perlu tergantung dengan manusia lain, harus mampu berdiri sendiri untuk mencapai tujuannya.

Adegan yang menampilkan hubungan horizontal dalam film ini tergolong cukup banyak. Yang pertama menonjol adalah adegan di menit ke 00:22:00, saat Yoki membunyikan klakson dan melambaikan tangannya keluar. Tindakan Yoki tersebut merupakan bentuk komunikasi nonverbal yang dapat diartikan sebagai pengganti ucapan salam dengan kata-kata. Kemudian salah seorang penduduk membalas lambaian tangan Yoki dengan mengangkat tangannya. Hal ini adalah salah satu bentuk menghormati penduduk yang dijumpainya, terlepas dari masalah Yoki mengenali mereka atau tidak.
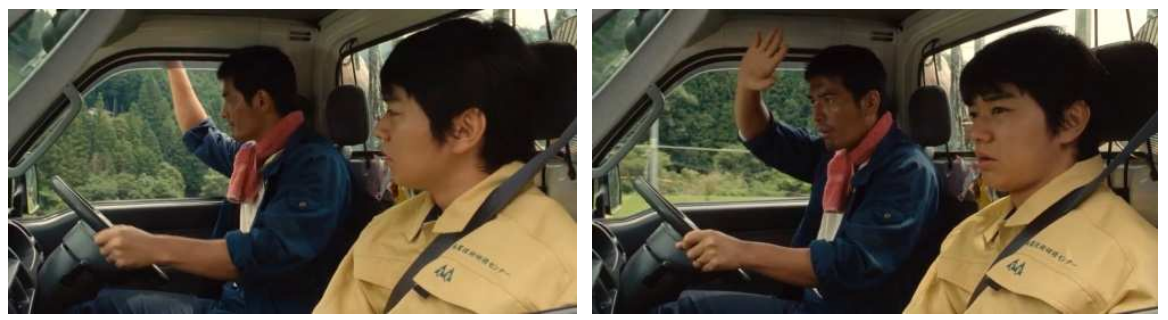

Gambar 9. Yoki melambaikan tangan pada penduduk setempat

Bentuk nilai budaya dan kearifan lokal dengan memberi salam juga terdapat di menit ke 00:24:57, kali ini memperlihatkan Yuki yang ingin memberi salam kepada Seiichi. Saat pertama kali Yuki ditempatkan untuk bekerja magang di Nakamura Lumber, hal pertama yang ia lakukan adalah langsung menemui pak kepala (Seiichi) di rumahnya. Jika Yoki memberi salam hanya dengan lambaian tangan, Yuki memberi salam dengan mengucapkan sumimasen (permisi) sambil membungkukkan badan.

Dari adegan tersebut, melalui tokoh Yuki, Shinobu mencoba memperlihatkan bahwa memberi salam adalah sebuah keharusan bagi masyarakat Jepang. Yuki yang tidak memiliki tata krama bahkan dengan senang hati mengunjungi rumah Seiichi untuk mengucapkan salam perkenalan dengan sopan. Jika kita perhatikan, orang-orang Jepang memang memiliki kebiasaan yang unik dalam hal 'membungkuk', yakni membungkuk hampir di setiap saat. Ketika bertemu saudara atau kerabat, meminta maaf, berkenalan, dan mengatakan permisi.

Kebiasaan ini telah diajarkan sejak kecil dan merupakan suatu hal yang wajib bagi masyarakat Jepang. Membungkuk ala Jepang ini disebut Ojigi. Ojigi ternyata bukan 
sekedar membungkuk saja, melainkan ada aturan-aturan tertentu sesuai maksud dan tujuannya, serta kepada siapa bungkukkan itu ditujukan.

Tidak hanya orientasi horizontal, dalam film ini ada juga adegan yang menunjukkan orientasi vertikal, yakni rasa ketergantungan kepada tokoh-tokoh atasan dan berpangkat. Seperti yang terjadi di menit ke 01:16:16, saat seluruh penduduk pria berkumpul di rumah Kepala Desa Toshiro untuk mengadakan musyawarah. Kegiatan tersebut bertujuan untuk mencari solusi dari permasalahan apakah Yuki boleh ikut mengambil bagian utama dalam festival akbar nanti. Adegan tersebut menunjukkan bahwa masyarakat desa Kamusari masih mengutamakan pendapat dari Kepala Desa Toshiro yang merupakan tokoh masyarakat.

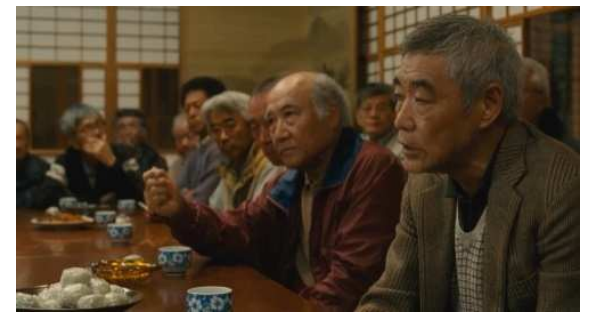

Gambar 10. Penduduk mengadakan musyawarah desa

Film ini berusaha menggambarkan kehidupan sehari-hari masyarakat pedesaan di Jepang yang berbudaya. Artinya, mereka masih tetap menjaga dan mempertahankan nilai-nilai budaya dan kearifan lokalnya. Masih menjunjung tinggi adat istiadat dan tradisi mereka. Selain menekankan pada gambar-gambar dengan latar belakang pedesaan yang hijau dan asri, Shinobu juga menciptakan dua karakter yang bertolak belakang. Yuki, orang kota yang acuh dan tidak memiliki tata krama, dan masyarakat desa Kamusari, masyarakat tradisional yang mengunggulkan tata karma diatas segalanya.

Tingkatan makna yang selanjutnya dari model semiotika Roland Barthes adalah mitos. Mitos berfungsi sebagai sistem pengetahuan metafisis dalam rangka menjelaskan asal-usul tindakan manusia. Bagi Barthes, mitos merupakan cara berpikir suatu kebudayaan mengenai suatu hal, cara untuk memahami dan mengkonseptualisasikan suatu hal tersebut. Mitos adalah hasil dari konotasi yang telah mantap, dan mitos yang mantap akan berubah menjadi ideologi.

Nilai budaya merupakan seperangkat nilai yang disepakati dan tertanam dalam suatu masyarakat, lingkup organisasi, lingkungan masyarakat, yang mengakar pada suatu kebiasaan, kepercayaan masyarakat (folk beliefs), simbol-simbol, dengan karakteristik tertentu yang dapat dibedakan satu dan lainnya sebagai acuan prilaku dan tanggapan atas apa yang akan terjadi atau sedang terjadi.

Selama ini, sebagian besar masyarakat menganggap bahwa nilai-nilai kebudayaan dan kearifan lokal itu sama. Padahal sebenarnya ini merupakan dua hal yang berbeda, walaupun perbedaan tersebut sangat tipis dan hampir tidak terlihat. Kebudayaan mencakup sesuatu yang kompleks yang diperoleh manusia sebagai anggota masyarakat, dan pembentukannya didukung dan diteruskan pula oleh anggota masyarakat. Sedangkan kearifan lokal dapat dipahami sebagai nilai-nilai atau pandangan-pandangan setempat (lokal) yang bersifat bijaksana, penuh kearifan, bernilai baik, yang tertanam 
dan diikuti oleh anggota masyarakatnya. Jadi, kearifan lokal merujuk pada lokalitas dan komunitas tertentu.

Kearifan lokal merupakan produk budaya, sesuatu yang berkaitan secara spesifik dengan budaya tertentu serta mencerminkan cara hidup suatu masyarakat tertentu, dikembangkan selama beberapa generasi dan mudah diadaptasi, serta tertanam di dalam cara hidup masyarakat sebagai sarana untuk bertahan hidup. Dari pengertian tersebut mulai nampak sedikit perbedaannya. Pada intinya adalah suatu kearifan lokal merupakan bagian dari budaya, namun suatu budaya belum tentu mengandung nilai kearifan lokal.

Bentuk nilai budaya dan kearifan lokal yang diwariskan secara turun-temurun dari generasi ke generasi secara konsisten akhirnya membentuk sebuah mitos. Nilai-nilai tersebut misalnya berbuat baik pada orang lain, toleransi antar sesama manusia, bekerja sama, bergotong-royong, musyawarah untuk mencapai mufakat, serta menjaga dan melestarikan alam. Dilihat dari sudut pandang agama, prinsip-prinsip budaya dan kearifan lokal ini merupakan bagian dari visi atau ideologi. Tidak hanya Islam, namun semua agama, bahkan sebuah kepercayaan rakyat seperti Shinto sekalipun.

Kearifan lokal merupakan kecerdasan manusia yang dimiliki oleh sekelompok manusia (etnis) yang diperoleh melalui pengalaman hidup serta terwujud dalam ciri-ciri budaya yang dimilikinya. Kearifan lokal juga merupakan bentuk kecerdasan yang dihasilkan oleh masyarakat pemilik kebudayaan itu. Sebuah kearifan lokal dihasilkan berdasarkan pengalaman yang dijalani sendiri sehingga menjadi milik bersama. Kearifan lokal Jepang misalnya, adalah wujud kecerdasan yang dihasilkan oleh pengalaman budaya masyarakat Jepang sendiri, bukan oleh pengalaman hidup bangsa lain. Singkatnya, kearifan lokal Jepang merupakan butir-butir kecerdasan, kebijaksanaan 'asli' yang dihasilkan oleh masyarakat Jepang.

Pengembangan dan penerapan kearifan lokal menjadi sangat penting dalam rangka mencerdaskan kehidupan bangsa. Kearifan lokal memiliki pertahanan terhadap unsurunsur eksternal dan mampu berkembang untuk masa-masa yang akan datang. Kepribadian suatu masyarakat ditentukan oleh kemampuan dan kekuatan kearifan lokal dalam menghadapi kekuatan dari luar. Jika nilai kearifan lokal hilang atau musnah, kepribadian bangsa pun akan memudar (Sujarwa, 2014).

Jadi, nilai budaya dan kearifan lokal memang sudah ada sejak zaman dahulu kala. Hai itu terbukti dari berbagai peninggalan tertulis maupun peninggalan-peninggalan lain seperti bangunan atau benda-benda yang digunakan sebagai sarana pemujaan. Nilainilai yang diwariskan secara turun temurun dengan konsisten inilah yang kemudian berubah menjadi sebuah mitos. Nilai budaya dan kearifan lokal berarti suatu kepercayaan yang telah tertanam dalam diri masyarakat mengenai baik-buruk atau pantas-tidak pantas terhadap sesuatu. Sesuatu (nilai) yang dianggap baik dan pantas lantas menjadi suatu budaya. Lebih spesifik lagi, nilai budaya yang dipertahankan oleh masyarakat akan berubah menjadi tradisi, sekaligus merupakan identitas budaya bagi masyarakat tersebut.

\section{KESIMPULAN}

Film ini tidak lain adalah agen untuk menciptakan sebuah propaganda. Ada dua hal yang menjadi inti dari film ini. Pertama, mengkonstruksikan pemahan khalayak 
tentang nilai budaya dan kearifan lokal masyarakat Jepang yang digambarkan sesuai dengan landasan kepercayaan Shinto. Shinobu dengan jelas mengunggulkan Shinto sebagai kepercayaan rakyat yang sangat baik, dengan memperlihatkan nilai-nilai ajarannya yang tidak dimiliki oleh agama atau kepercayaan lain.

Kedua, memotivasi para pemuda untuk ikut serta dalam proses pelestarian hutan, salah satunya adalah dengan menjadi seorang jagawana atau petani hutan. Shinobu mengajak seluruh masyarakat untuk lebih menghargai alam dan tidak merusaknya dengan nafsu keserakahan duniawi semata. Seperti dalam ajaran dasar Shinto yang mengajarkan manusia untuk menjalani kehidupan yang harmonis dengan alam.

Pada dasarnya, bertahan atau tidaknya nilai budaya dan kearifan lokal merupakan sebuah pilihan masyarakat sendiri. Ingin mempelajari kebudayaan baru seiring dengan perkembangan zaman atau tetap berpegang teguh pada tradisi lokal. Solusi bijaknya adalah dengan mengadaptasi kebudayaan baru yang sesuai dengan nilai-nilai kepercayaan masyarakat setempat dan tidak menghilangkan kebudayaan aslinya. Berjalan beriringan dengan harmonis seperti Shinto dan Buddha.

\section{DAFTAR PUSTAKA}

\section{Buku :}

Ardianto, Elvinaro dan Bambang Q-Anees .2007. Filsafat Ilmu Komunikasi. Bandung : Simbiosa Rekatama Media

Budiman, Kris .2011. Semiotika Visual.Yogyakarta : Jalasutra

Burton, Graeme .2012. Media dan Budaya Populer.Yogyakarta : Jalasutra

Eco, Umberto .2011. Teori Semiotika.Yogyakarta : Kreasi Wacana

Fiske, John .2007. Cultural and Communications Studies. Yogyakarta : Jalasutra

Imron, M. Ali .2015. Sejarah Terlengkap Agama-Agama di Dunia (Dari Masa Klasik Hingga Modern). Yogyakarta : IRCiSoD

Karina, Nina dan Retno Sasongkowati .2013. History of The World (Sejarah Dunia Kuno dan Modern).Yogyakarta : Indoliterasi

Mabruri, Anton .2013. Manajemen Produksi Program Acara TV. Jakarta : Gramedia Widiasarana Indonesia

Mangunjaya. 2006. Hidup harmonis dengan alam. Jakarta : Obor Indonesia

Maryaeni .2005. Metode Penelitian Kebudayaan. Jakarta : Bumi Aksara

Morissan .2013. Teori Komunikasi. Bogor : Ghalia Indonesia

Mulyana, Deddy .2005. Komunikasi Efektif. Bandung : Remaja Rosdakarya

Ross, Catrien .2007. Mistik Jepang. Yogyakarta : Pinus Book

Samovar, Larry A, dkk. 2010. Komunikasi Lintas Budaya (Communication Between Cultures). Jakarta : Salemba Humanika

Sobur, Alex .2009. Semiotika Komunikasi. Bandung : Remaja Rosdakarya

Sujarwa .2014. Ilmu Sosial dan Budaya Dasar (Manusia dan Fenomena Sosial Budaya). Yogyakarta : Pustaka Pelajar 
The International Society for Educational Information.1989.Jepang Dewasa Ini Tokyo, Japan.

Vera, Nawiroh .2014. Semiotika dalam Riset Komunikasi. Bogor : Ghalia Indonesia Wibowo, Indiwan Seto Wahyu .2013. Semiotika Komunikasi - Aplikasi Praktis Bagi Penelitian dan Skripsi Komunikasi. Jakarta : Mitra Wacana Media

\section{Internet :}

https://en.wikipedia.org/wiki/Wood_Job! diakses pada tanggal 11 Desember pukul 23:40 https://id.wikipedia.org/ Perkembangan_Film diakses pada tanggal 9 Januari pukul $12: 19$

http://wirasaputra. wordpress.com/2011/10/13/nilai-budaya-sistem-nilai-dan-orientasinilai -budaya diakses pada tanggal 13 Januari pukul 11:20

https://asianwiki.com/Wood Job diakses pada tanggal 15 Januari pukul 12:20 http://wiki.d-addicts.com/Waterboys diakses pada tanggal 18 Februari pukul 9:42 http://asianwiki.com/Swing_Girls diakses pada tanggal 18 Februari pukul 10:49 https://asianwiki.com/Wood Job diakses pada tanggal 15 Januari pukul 11:20 http://stbalia.ac.id/modules diakses pada tanggal 24 Februari pukul 18:05 https://id.wikipedia.org/wiki/Shinto diakses pada tanggal 24 Februari pukul 14:00 http://deviciptyasari.blogspot.co.id/2014/01/shintoisme-dan-shamanisme.html diakses pada tanggal 24 Februari pukul 14:36

http://m.tribunnews.com/internasional/2015/07/29/di-jepang-memotong-pohon-tuajuga-harus-gunakan-sesajen

http://fransiska-aprilia-fib13.web.unair.ac.id/artikel_detail-104292/Pengertian-BudayaNilainilai-Budaya-dan-Karakteristik-Budaya.html diakses pada tanggal 12 Januari pukul $13: 41$

http://duniaglobalislam.blogspot.co.id/2011/05/dakwah-dengan-berpijak-padakearifan.html diakses pada 20 Februari pukul 22:34

http://republika.co.id/berita/nasional/umum/14/03/17/jaga-kearifan-lokal-ri-perlucontoh-jepang.html

http://jembatanimpian.wordpress.com/2011/12/05/konsep-religius-manusia-jepang.html http://ajaran-buddha.blogspot.co.id/2008/05/nasibtakdir.html 